\title{
ELMEOLVASÁS ÉS MACHIAVELLIZMUS: A MANIPULÁCIÓ SZITUATÍV FELTÉRKÉPEZÉSE
}

\author{
SZABÓ EDIT - BERECZKEI TAMÁS
}

PTE BTK Pszichológia Intézet

E-mail: bereczkei.tamas@pte.hu

Beérkezett: 2014. október 10. - Elfogadva: 2014. december 20.

\begin{abstract}
A sikeres manipuláció elméletileg magas szintü elmeolvasási képességet feltételez, ám az eddigi kutatások, amelyek a machiavellisták vizsgálatára irányultak, nem tudták bizonyítani ezt a tételt. Felmerül ezért a lehetöség, hogy a machiavellisták gyengébb kognitív szinten teljesitenek, mint ahogyan korábban gondolták. Ennek azonban ellentmondanak azok a kísérleti eredmények, amelyek szerint rendkíül sikeresen manipulálnak másokat, és ehhez felhasználják a társas szituáció résztvevoöiről alkotott benyomásaikat is. Feltételeztük, hogy ez az ellentmondás feloldható, ha új megközelítésbe helyezzük a machiavellisták elmeolvasását. Vizsgálatunkban egy olyan új módszert használtunk, amely párbeszédekre épitve valós társas kontextusokhoz hasonlító ingeranyagot mutat be, és fókuszba emeli a manipulatív taktikák alkalmazását is. Eredményeink alapján a machiavellisták jobban oldják meg a dialógusokra épülö történetek mentalizációs feladatait, mint a narratívákon alapuló történetekét. Emellett másoknál jobban teljesitenek a manipulatív jellegü történetek elmeolvasás-feladataiban, és kifejezett érzékenységet mutatnak a megtévesztés szándékosságának felismerésére. Mindezek tükrében új megvilágításba kerülhet a machiavellisták elmeolvasása.
\end{abstract}

Kulcsszavak: elmeolvasás, machiavellizmus, manipuláció

\section{ELMÉLETI HÁTTÉR}

A fajtársak megtévesztése fontos szerepet játszhatott az emberi gondolkodás fejlődésében. Az ún. machiavelliánus intelligenciaelmélet szerint a megtévesztés egyenesen az a szelekciós erő, amely a humánspecifikus kognitív képességek kialakulása mögött húzódik (Whiten és Byrne, 1997; Lyons, CALdwell és SChultz, 2010). E hipotézis értelmében az erőforrásokért való küzdelmek során egyre fejlettebb megtévesztési és manipulációs taktikák alakultak ki, ezek egyre finomabb 
csalódetekciós mechanizmusokat hívtak elő, amelyek aztán még kiforrottabb manipulációs módszereket generáltak, és így tovább, s ez a fegyverkezési verseny vezethetett az intelligencia gyors fejlődéséhez a fóemlősök, azon belül is a humán evolúció során (PAÁL és BERECZKEI, 2007; BERECZKEI, 2009).

Szociálpszichológiai kutatások alapján (CHRISTIE és GEIS, 1970) a machiavellizmus olyan magatartásként definiálható, amelyben az egyén a másik embert a saját céljai eléréséhez szükséges eszközként használja fel (WILSON, NEAR és Miller, 1996; Gunnthorsdottir, MCCabe és Smith, 2002; Bereczkei, 2009). A definíción túl pedig egy olyan komplex magatartásformát jelent, amely egyrészt egy cinikus világnézeti stílust foglal magában, másrészt pedig bizonyos, manipulációra és megtévesztésre alapuló viselkedési taktikák alkalmazását (MCILWAIN, 2003). A machiavellisták az átlagnál jóval ügyesebben manipulálnak, s igen meggyőzően vezetnek félre másokat - egy szituációnak gyakran már az első lépésében készek a másik kihasználására (BERECZKEI, 2009).

\section{Jó elmeolvasók-e a machiavellisták?}

Ahhoz, hogy valaki sikeresen manipuláljon másokat, hogy felismerje mások - sokszor még önmaguk számára is rejtve maradó - gyenge pontjait, nagyon valószínűnek tűnik, hogy szükség van az elmeolvasásra. Vagyis arra a képességre, hogy felmérje és a maga érdekében felhasználhassa mások tudását, szándékait, elképzeléseit, ismereteit vagy éppen azok hiányát. Ebből következően a machiavellizmus magas fokának együtt kell(ene) járnia a mentális állapottulajdonítás, az elmeolvasás fejlettségével. Ezt az elméleti elgondolást több vizsgálat is megkísérelte empirikusan igazolni, azonban meglepetésre sikertelenül (LYONS, CALDWELL és SCHULTZ, 2010; McIllain, 2003; PaÁl és BereczKeI, 2007; PAÁl, 2011).

A manipuláció és az elmeolvasó képesség között vagy nem találtak összefüggést az erre irányuló kutatások, vagy egyenesen azt mutatták ki, hogy a machiavellisták az átlagosnál is rosszabb elmeolvasók (PAÁL és BERECZKEI, 2007; Ali és ChAmORRO-PREMUZic, 2010). LyONS és munkatársai vizsgálatukban (2010) arra az eredményre jutottak, hogy a machiavellisták az elmeolvasás mind emocionális, mind kognitív típusában másoknál gyengébben teljesítenek. A különböző kutatások eltérő módszereket is alkalmaztak a mentális állapottulajdonítás mérésére: a kísérleti alanyoknak a tekintet, arckifejezés vagy hanglejtés alapján kellett a látott vagy hallott ingert adó személy érzelmeit beazonosítaniuk (ALI és CHAMORROPREMUZIC, 2010; LyONS és mtsai, 2010), illetve különböző történeteket megértve a szereplők gondolatait, vágyait, szándékait helyesen értelmezniük (KINDERMAN, Dunbar és Bentall, 1998; LyOns és mtsai, 2010; PaÁl és Bereczkei, 2007). Az eredmények azonban egyik esetben sem igazolták a machiavellisták elmeolvasás terén elvárt sikerét.

A felnőtt elmeolvasásban mutatott hiányosságok mellett más vizsgálatokból az derült ki, hogy a machiavellisták alacsonyabb szintű empátiás képességgel és érzelmi intelligenciával rendelkeznek, s gyengébben teljesítenek az érzelmek megértése terén is (Austin, Farrelly, Black és Moore, 2007; Mcillwain, 2003). 
Mindezekből pedig elméletileg az a következtetés vonható le, hogy nincsenek kimagasló képességeik mások megértésében, sőt gyengébben navigálnak a társas megismerés területein, és alacsonyabb kognitív szinten teljesítenek, mint ahogy azt korábban feltételezték.

Ez azonban ellentmondani látszik azoknak a kutatási eredményeknek, amelyek szerint a machiavellisták kifejezetten sikeresek mások megtévesztésében (CzIBOR és BERECZKEI, 2012). Továbbá már a korai vizsgálatokból is az a kép rajzolódik ki, hogy nagy sikereket érnek el azokban a feladatokban is, amelyekben módjukban áll nyereséges üzletet kötni, előnyös szövetséget alakítani vagy vezetői szerepet vállalni (Christie és Geis, 1970; Cherulnik, WaY, AMEs és Hutto, 1981; idézi Bereczkei, DeÁk, PAPp, Perlaki és ORSI, 2013).

\section{Mitöl sikeres a machiavellista manipuláció?}

Egy bizalomjátékra épülő vizsgálatból kiderült, hogy a magas machiavellizmuspontszámmal jellemezhető játékosok kevésbé viszonozták a partnerüktől kapott juttatásokat, és a játék végére nagyobb jövedelemre tettek szert (GUNNTHORSDOTTIR és mtsai, 2002). Ez is mutatja, hogy a machiavellisták könnyen hátat fordítanak korábbi szövetségeseiknek is, ha ez előnyükre válik. Hűvös fejjel választják ki azt az optimális stratégiát, amely leginkább megfelel a pillanatnyi érdekeiknek. Ezt hangsúlyozzák azok az eredmények is, amelyek szerint a machiavellisták elsősorban azokat lopják meg, illetve tévesztik meg, akik bíznak bennük (HARRELL és HARTNAGEl, 1976; Wilson, NEAR és MiLler, 1996). S miközben általában véve normasértők, vagy legalábbis normakerülők, rögvest normakövetővé válnak, ha érdekük úgy kívánja, vagy a helyzet úgy hozza - gyakran alkalmazzák a megtévesztő együttműködés eszközét (BERECZKEI, BIRKÁS és KEREKES, 2010).

Rugalmas alkalmazkodásuk lehet az oka annak is, hogy sokszor kerülnek ki a versengés győzteseként. Egy közjavak játékra épülő vizsgálatban a machiavellisták a többieknél kevesebbet fizettek be a csoport számlájára, s a játék végén nagyobb összeget vittek haza - mind az együttműködő, mind a versengő szituációban sikeresebbek voltak a kevéssé machiavellistáknál (CZIBOR és BERECZKEI, 2012). Az elemzések azt mutatták, hogy jobban figyeltek a többi játékos viselkedésére, és erősen kontextusfüggő stratégiát követtek. Érzékenyebbek voltak a társas szituáció jelzéseire, és döntéseikben nagyobb szerepet játszott a csoport többi tagjának viselkedése.

Egy $f$ MRI-vizsgálat tanúsága szerint is folyamatosan monitorozzák társaik viselkedését a machiavellisták, és saját érdekeiknek megfelelően, ám a többiek viselkedéséhez igazodva hozzák meg döntéseiket (BERECZKEI és mtsai, 2013). A vizsgálat olyan agyi területeken mutatott ki fokozott aktivitást, amelyek a következtetések és a jutalomvezérelt döntések kialakítását szabályozzák. Az eredmények azt sugallják, hogy a machiavellisták olyan kognitív képességek birtokában vannak, amelyek alapján képesek a többiek viselkedéséből arra következtetni, melyek a lehetséges és számukra előnyös reakciók és viselkedésformák, s emellett képesek jó időben észlelni a jutalom megszerzése során felmerülő problémákat és az érdekeiket sértő fenyegetéseket. 


\section{Hogyan finomitható az elmeolvasó képesség vizsgálata?}

Ellentmondás feszül tehát a machiavellisták elmeolvasásban és mások megismerése terén mért gyengébb teljesítménye és a manipulatív, önérdek-érvényesítő viselkedésben mutatott kimagasló teljesítménye között. Habár úgy tűnik, hogy képesek felmérni a többiek szándékát és várható viselkedését, ennek nyomát az elmeolvasást mérő feladatokban ez idáig nem sikerült kimutatni. Elképzelhető, hogy a korábban alkalmazott tesztek olyan feladatok elé állították a machiavellistákat, amelyeknek helyes megoldására egyrészt nem voltak kellően motiváltak, másrészt nem alkalmazhatták manipulációs, illetve haszonközpontú stratégiáikat (PAÁL és BerECZKeI, 2007; PAÁL, 2011). Felmerül tehát a kérdés, hogyan lehet a mentális állapottulajdonítás mérését tovább árnyalni, pontosítani egy olyan irányban, amely nagyobb hangsúlyt helyez a manipuláció és az elmeolvasás kapcsolatára.

Az elmeteóriát mérő korábbi vizsgálatok egy része történetek megértésére épült (KINDERMAN és mtsai, 1998; LYONS és mtsai, 2010; PAÁl és BERECZKEI, 2007; PAÁl, 2011). PAÁL és BereczKeI vizsgálatukban (2007) egy olyan tesztet alkalmaztak, amely különböző bonyolultságú élethelyzeteket, interperszonális kapcsolatokat és konfliktusokat ír le. A KINDERMAN és munkatársai által létrehozott IMT-tesztet (Imposing Memory Task,1998) felhasználva s azt mintául véve, a bemutatott történetek szándékos vagy véletlen megtévesztést, illetve félrevezetést tartalmaztak. Ezek a történetek azonban leíró jellegűek voltak, és számos olyan mentalizációs kifejezést tartalmaztak, amelyek a szereplők érzéseit, gondolatait, szándékait direkt leírják, ahelyett, hogy arra a történéseken keresztül utalnának, s a kísérleti személyeknek maguknak kellene elvégezniük a mentalizáció feladatát (lásd Függelék: narratív történet).

Jelen vizsgálatban éppen ezért olyan történetek is szerepelnek, amelyek egyáltalán nem tartalmaznak a szereplők mentális állapotára vonatkozó leírást, hanem csak párbeszédeket (lásd Függelék: dialogikus történet). Ezekből a történetekből a kísérleti személyek azt ismerhetik meg, hogy a szereplők mit mondanak, mit tesznek, s közben miként viselkednek - senki nem „súgja meg” nekik, hogy valamely szereplő éppen mit érez vagy miként gondolkodik. Ezáltal pedig a bemutatott szituációk hasonlóvá válnak a mindennapi társas kontextusokhoz, s közelednek a valós elmeolvasás körülményeihez. A valós személyes interakcióban a machiavellisták ugyanis többnyire jól teljesítenek, és tipikusan azokban a szituációkban érik el a legnagyobb sikereket, amelyekben lehetőségük van szemtől szemben találkozni a másik emberrel (WILSON, NEAR és MILLER, 1998).

Vizsgálatunkban emellett különböző, kifejezetten manipulatív taktikák bemutatása is helyet kapott. A machiavellisták, bár gyengébb általános érzelmi intelligenciával jellemezhetők, ha azonban érzelmi manipulációról van szó, abban saját bevallásuk szerint nagyon is otthonosan mozognak (AUSTIN és mtsai, 2007). A megtévesztésre irányuló viselkedésformák vizsgálatunkban társas szituációkba lettek foglalva. A kísérleti személyek olyan manipulatív szituációkat, illetve trükköket, taktikákat ismerhetnek meg (és fel), amelyek jellemzően sikeres megtévesztéshez vezetnek. Ezáltal pedig a machiavellistáknak lehetőségük adódik a manipulációhoz szükséges készségeiket előhívni. 


\section{HIPOTÉZISEK}

Jelen kutatás célja, hogy kapcsolódási pontokat keressen az elmeolvasás és a machiavellizmus között, egy olyan, történetekre épülő vizsgálati módszert alkalmazva, amely nagyobb hangsúlyt helyez a manipuláció és a mentális állapottulajdonítás viszonyrendszerének feltérképezésére.

Mivel a történetek nagy része valós szituációkat imitáló, azokat a lehető legjobban megidéző mentalizációs ingereket tartalmaz, megengedi a valós helyzetekre jellemző viselkedések bemutatását. Feltevésünk szerint a valóshoz hasonlító társas kontextusok megjelenítése jobban motiválja a machiavellistákat az elmeolvasásra, és jobb teljesítményt érnek el az ezt mérő feladatokban.

A történetek kifejezetten manipulatív taktikákat is bemutatnak, olyanokat, amelyek szokott módon a megtévesztők sikeréhez vezetnek, s amelyek felismeréséhez és értelmezéséhez a machiavellistáknak lehetőségük adódik manipulációs készségük alkalmazására (bár közvetetten, hiszen nem ők maguk manipulálnak). Feltételezhetően jóval könnyebben ismerik fel a tipikus manipulatív taktikákat azok, akik maguk is alkalmaznak ilyeneket s hasonlókat. Ezek a machiavellisták számára olyan ismerős helyzetet jelenthetnek, amelyben otthonosan mozognak. Hiszen ők azok, akik képesek hideg fejjel, a szituációhoz és a körülményekhez rugalmasan alkalmazkodva, a szabályokat megkerülve és jól improvizálva kihasználni az interperszonális kapcsolatokban számukra adódó lehetőségeket és előnyöket. Ök azok, akik mindehhez előszeretettel alkalmaznak a társas szituáció résztvevőit befolyásoló taktikákat (JONES és PAULHUS, 2009).

\section{MÓDSZER}

\section{Vizsgálati személyek}

A résztvevők valamennyien 19-29 év közötti, önként jelentkező egyetemi hallgatók voltak a Pécsi Tudományegyetem különböző karairól. Az eredmények 74 személy vizsgálatából származnak, közülük 31 férfi, 43 nő.

\section{Vizsgálati eszközök}

A mentális állapottulajdonítási képesség felmérésére történetekre építő megértési feladatot alkalmaztunk, amelyhez hasonlót a nemzetközi kutatásokban is használnak a felnőtt elmeolvasás vizsgálatára (KINDERMAN és mtsai, 1998; LYONS és mtsai, 2010; PAÁL és BERECzKEI, 2007). Vizsgálati anyagunk 15 történetből áll, amelyeket a hozzájuk kapcsolódó válaszlapok követnek. Minden történet egy-egy szituációsort mutat be, amelyben szándékos vagy véletlen megtévesztés, félrevezetés jelenik meg. Megértésük az intencionalitás különböző szintjeit mutató elmeolvasási képességet igényel. 
A történeteket hangjáték formájában vetítettük le a kísérleti személyeknek, ami azt jelenti, hogy egy-egy történet minden egyes szereplöjének más-más személy kölcsönözte a hangját. A hangfelvétel meghallgatása közben a kísérleti személyek az adott történet szereplőinek listáját látták a kivetítőn.

\section{Történettípusok}

Narratív történetek. Ebbe a csoportba 5 olyan történet tartozik, amelyet PAÁL vizsgálata alapján (PAÁl és BereczKeI, 2007; PAÁL, 2011; Kinderman és mtsai, 1998 nyomán) változatlan formában használtunk fel. E történetek általános jellemzői, hogy leíró jellegűek, vagyis előzményeket és következményeket leírva ábrázoló elbeszélések. Párbeszédet nem tartalmaznak, legfeljebb a leírást megszakítva, olykor egy-egy szereplő egymondatos megszólalása szerepel bennük. Az e típusba tartozó történetek mindegyikének szövegében számos olyan mentalizációs kifejezést találunk, amelyek a szereplők gondolataira, érzéseire, szándékaira vonatkoznak. (Például „Eszter nem hitte el ezt a kifogást”, „Anna... titokban szerelmes volt Péterbe”, „tudták, hogy a fogoly nyilvánvalóan nem akarja elárulni társait”) (lásd Függelék).

Dialogikus történetek. Ez a típus 5 olyan történetet foglal magában, amelyek szintén PAÁL, valamint KINDERMAN vizsgálatának ingeranyagából származnak (Kinderman és mtsai, 1998; PAÁl és BERECZKeI, 2007; PAál, 2011), ám jelentős változtatásokon estek át. Minden történetet átírtunk, és úgy dramatizáltunk, hogy a leírás helyett párbeszédekre épüljön, azaz leíró elbeszélés helyett párbeszédekből - a szereplők beszélgetéseiből - bontakozzon ki a szituációk sora. A párbeszédek mellett csak a minimálisan szükséges, a környezetet és a körülményeket tárgyilagosan ábrázoló leírás, narráció szerepel. Ezek a történetek a szereplők mentális állapotára vonatkozóan egyetlen direkt mentalizációs kifejezést sem tartalmaznak. A dialogikus történetekből a kísérleti személyek arról szerezhetnek információt, hogy az egyes szereplők mit mondanak, és közben hogyan viselkednek, cselekednek - akárcsak a valós helyzetekben (lásd Függelék).

Manipulatív taktikus történetek. Az ide tartozó 5 történetet magunk hoztuk létre. Felépítésük formailag teljesen megegyezik a dialogikus történetekével: párbeszéd alapú szövegek minimális környezetleíró narrációval, amelyek mentalizációs kifejezéseket nem tartalmaznak. Amiben azonban lényegesen eltérnek a fent leírt történettípustól, az az, hogy egy-egy jól megragadható, tipikus megtévesztő taktikát is magukban foglalnak. Ezek a történetek tehát olyan taktikákat jelenítenek meg, mint például a hízelgés, a támadólag védekezés, az áldozat szerepének játszása vagy a racionalizálás, amelyeket a szakirodalomban jellemzően a manipulátorok, és különösen a machiavellisták jellemzésére alkalmaznak (például Buss, Gomes, Higgins és Lauerbach, 1987; MCIlwain, 2003; Grams és Rogers, 1990; Vangelisti, Daly és Rudnick, 1991; utóbbiakat idézi Jones és Paulhus, 2009). Valós, megtörtént esetek inspirálták, illetve az általuk tipizált manipulatív taktikák képezik ezeknek a történeteknek az alapját (SimON, 2009; SíkLAKI in SimON, 2009) (lásd Függelék). 


\section{2. Állításpárok}

A történetekhez tartozó állítások között szerepel néhány faktuális állításpár, amely az adott történet ténybeli összefüggéseire kérdez rá. (Például „A) Lilla és Anna unokatestvérek voltak. B) Lilla és Anna barátnők voltak.")

Az állítások másik, nagyobb része az elmeolvasás felmérését célozza. Ezek felosztása alapvetően kettős.

\section{Személyközpontú állításpárok}

Az ebbe a típusba tartozó állítások jellemzője, hogy a történetek szereplőit név szerint jelölik, és úgy mutatják be azok gondolatait, vélekedéseit vagy vágyait, hogy belehelyezkednek a szereplők egyéni nézőpontjába - többszörösen is, több szereplő nézőpontját egymásba építve. (Például „A) Melinda azt gondolta, hogy Andrásban megerösödik a gondolat, hogy Simon nem kedveli Melindát. B) Melinda azt gondolta, hogy Andrásban nem erösödik meg a gondolat, hogy Simon nem kedveli Melindát.”) A korábbi, történetekre alapuló elmeteória-vizsgálatokban is ilyen típusú állításpárokat alkalmaztak (KINDERMAN és mtsai, 1998; PAÁl és BERECZKEI, 2007; PAÁL, 2011).

\section{Szituáció-központú állításpárok}

Az előbbiektől eltérően ezek az állítások egy lényeges cselekvés vagy történés köré épülnek, és a szereplők gondolatainak, vélekedéseinek felmérése magából a helyzetből indul ki. Itt csak a főszereplő jelenik meg név szerint, a többi szereplő pedig kategorizálva - kategóriájukat a szituációból fakadó szerepük határozza meg. (Például „A) András barátnője pontosan felidézte Andrásnak a nőket becsmérlo” megjegyzését, amit András barátja azért tett, mert nem akarta a lányra bízni a CD-ket. B) András barátnője nem idézte pontosan Andrásnak a nöket becsmérlö megjegyzését, amit András barátja azért tett, mert nem volt biztos a randevújában.")

A mentális állapottulajdonítás felmérésére szolgáló állításokon belül az alábbi két specifikus állításpárt is bevezettük:

\section{Szándékos-véletlen állitáspárok}

Ezek az állítások specifikusan a megtévesztés szándékosságára kérdeznek rá. Bár a korábbi vizsgálatokra is jellemző volt, hogy a történetek egyik fele szándékos, másik fele pedig véletlen megtévesztést, illetve félrevezetést mutat be, tudomásunk szerint mindeddig nem vonták vizsgálat alá azt a kérdést, hogy a kísérleti személyek körében milyen eltérések mutatkozhatnak e tekintetben. Vagyis, bár a történetekből egyértelműen kiderül, hogy szándékos vagy véletlen megtévesztés történt-e (vizsgálatunkban minden történetben van a szándékosságot nemcsak megerősítő, de a másik eshetőséget kizáró elem is az egyértelműség kedvéért), ez idáig nem vonták górcső alá, hogy a vizsgálati személyek valóban szándékosnak ítélik-e a szándékost és véletlennek a véletlent. Ezért minden történethez tartozó 
válaszlapon szerepel egy olyan kérdés is, amely a történetben bemutatott megtévesztés szándékos voltára kérdez rá (,A történetben bemutatott megtévesztés szándékos volt. A) Igen B) Nem").

\section{Cinikus-naiv állitáspárok}

Ezek az állítások nem az igaz-hamis dimenzió mentén különböznek, hanem arra vonatkoznak, hogy mennyire hajlandó a kísérleti személy felmenteni a megtévesztőt vagy megbocsátani neki. (Például „A) András barátnöje hazudott Andrásnak, hogy rossz szinben tüntesse fel elötte a barátját. B) András barátnöje nem hazudni akart Andrásnak, csak nem emlékezett pontosan arra, mit is mondott András barátja.") Itt tehát egyegy olyan állításpárról van szó, amelynek egyik tagja jóhiszemü, jóindulatú hozzáállást tükröz a főszereplőhöz és a szituációhoz, másik tagja viszont negatív, gyanakvó álláspontot képvisel - miközben a bemutatott történet alapján mindkettő igaz lehet.

\section{Mach IV teszt}

A machiavellizmus mérésére a CHRISTIE és GEIS (1970) által kidolgozott Mach IV kérdőívet használtuk. A kérdőív 20 tételt tartalmaz, amelyek egyik fele Niccolò Machiavelli $A$ fejedelem című írásának szellemiségét tükrözi, másik fele pedig fordított tételként ezzel ellentétes állításokból áll. A tételekkel való egyetértés mértékét a kísérleti személyek egy hétfokú Likert-típusú skálán jelzik, ahol az „egyáltalán nem értek egyet” (1) és a „teljes mértékben egyetértek” (7) állítások határozzák meg a két szélső értéket.

\section{A vizsgálat menete}

A vizsgálatot kis csoportokban végeztük el. A kísérleti személyek anonim módon és önként vettek részt a kutatásban, s a részvételükért pénzjutalomban részesültek. A 15 történetet egyesével hallgatták meg, majd minden egyes történetet követően a vizsgálat kezdetén kiosztott válaszlapokon bejelölték a helyesnek ítélt állításhoz tartozó betűjelet. A válaszlapok kitöltésére szánt időt nem korlátoztuk. A Mach IV kérdőívet a vizsgálati személyek egyénileg, online elérhető formában töltötték ki.

\section{Adatkiértékelés}

Minden történettípus minden történetéhez egy-egy válaszlap tartozott, amelyen az állításpárok szerepeltek. A kísérleti személyeknek 'A' és 'B' válaszlehetőség közül kellett kiválasztaniuk azt, amelyikkel egyetértenek. A mentalizációs feladatokban elért teljesítményt úgy mértük, hogy a hibátlan megoldásokat számoltuk össze. A specifikus mentalizációs állításpárokat külön kezeltük. A naiv-cinikus állításpárok esetén, mivel nem igaz-hamis állításokról van szó, azt számoltuk össze, 
hányszor ítélték meg naivan, illetve cinikusan a kérdést a kísérleti személyek. A szándékosság kérdésében pedig nem csupán a hibákat vettük figyelembe, hanem azt is, hogy amikor a vizsgálati személyek hibáztak, a szándékost ítélték véletlennek, vagy fordítva, a véletlent szándékosnak.

\section{EREDMÉNYEK}

\section{Narratív történetek és machiavellizmus}

Összehasonlítva az elmeolvasás-feladatok (személyközpontú és szituáció-központú állításpárok) helyes megoldásait, a machiavellizmus marginálisan szignifikáns negatív összefüggést mutatott a narratív történetek hibátlan megoldásaival $(\mathrm{F}[4,73]=2,37, p=0,061)$ (lásd 1. ábra $)$. Ez azt jelzi, hogy minél magasabb machiavellizmus jellemez valakit, annál gyengébben teljesít a narratív történetek mentális állapottulajdonítást felmérő feladataiban.

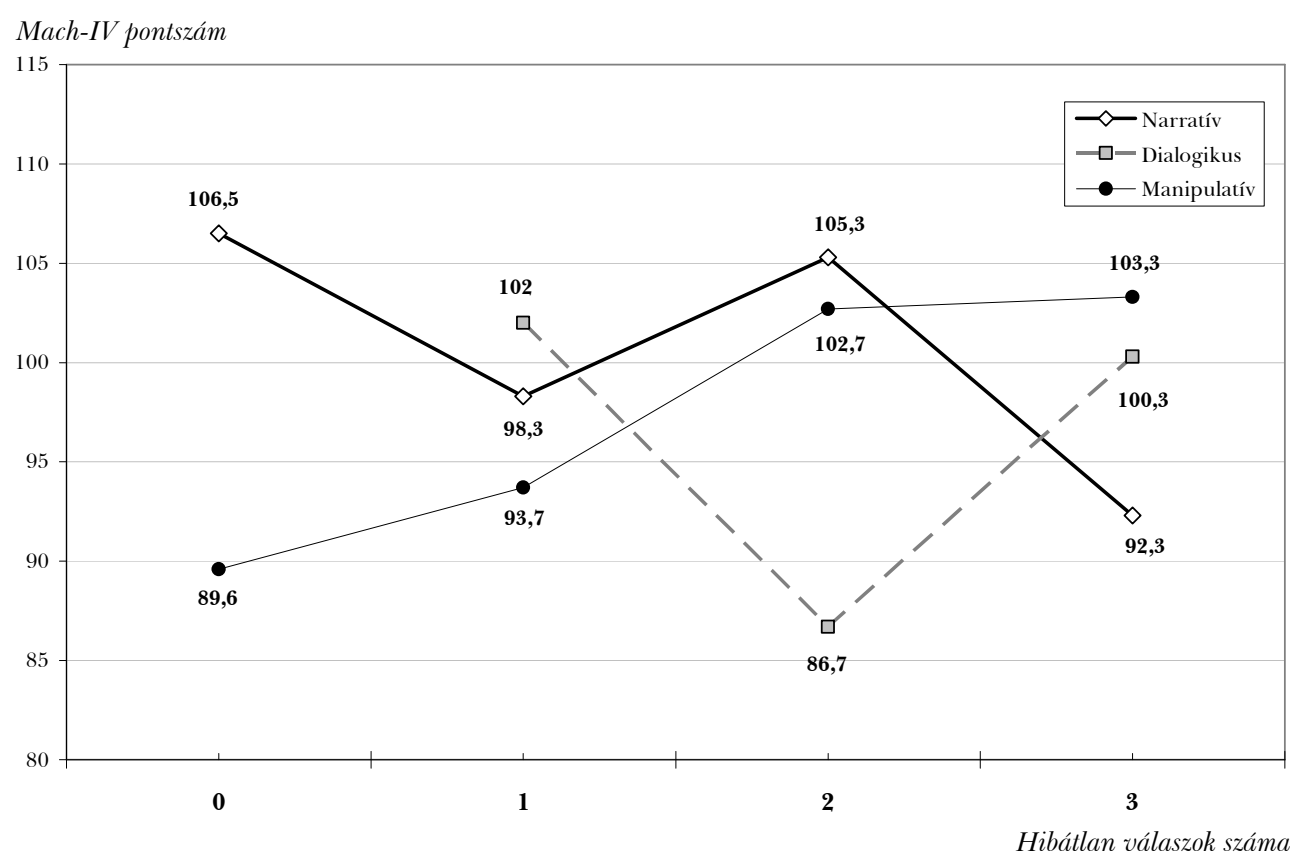

1. ábra. A háromféle történetben adott hibátlan válaszok (0, 1, 2, 3 vagy annál több) száma és a machiavellizmus összefüggése 


\section{Dialogikus történetek és machiavellizmus}

A dialogikus történetekben nem találtunk számottevő összefüggést a machiavellizmus foka és az elmeolvasás-feladatok teljesítése között $(\mathrm{F}[4,73]=1,60, p>0,05)$ (lásd 1. ábra).

\section{Manipulatív taktikus történetek és machiavellizmus}

A helyes megoldásokat összehasonlítva szignifikáns pozitív összefüggés mutatkozott a machiavellizmus mértéke és a manipulatív taktikus történetek elmeolvasást mérő feladatainak hibátlan megoldásai között $(\mathrm{F}[4,73]=2,75, p<0,05)$ (lásd 1. ábra). A magas machiavellista személyek tehát a többieknél jobban teljesítettek e történetek mentális állításainak megítélésében.

\section{Cinikus-naiv állitások és machiavellizmus}

Pozitív korrelációt találtunk a machiavellizmus és a cinikus állítások választása között (Pearson $r=0,246 ; p<0,05)$, vagyis a machiavellisták az elvárásoknak megfelelően többször helyezkedtek a cinikus álláspontra a naivval szemben.

\section{Szándékos-véletlen állitások és machiavellizmus}

A narratív, illetve a manipulatív taktikus történetekben bemutatott megtévesztések szándékosságának megítélésében megmutatkozott egyfajta tendencia, amely összefügg a machiavellizmus mértékével. A szándékos megtévesztésre épülőket pontosabban ítélték meg a machiavellisták, tendenciózus összefüggést találtunk mind a narratív $(\mathrm{F}[1,73]=3,62, p=0,061)$, mind a manipulatív taktikus $(\mathrm{F}[1,73]=3,16$, $p=0,080)$ történetek esetében. Ez azt jelzi, hogy a magas Mach-személyek jellemzően felismerték a szándékosságot, és nem ítélték a szándékos megtévesztést véletlen félrevezetésnek vagy félreértésnek, ellentétben az alacsony machiavellizmusértékeket mutatókkal, akik ezt többször elvétették.

A véletlen megtévesztést tartalmazó történetek megítélésében nem mutatkozott ilyen különbség, sem a narratív $(\mathrm{F}[1,73]=0,11, p>0,05)$, sem a manipulatív taktikus $(\mathrm{F}[1,73]=1,62, p>0,05)$ történeteket tekintve. Ez pedig azt jelenti, hogy az alacsony és a magas machiavellista személyek egyaránt jól felismerték ezeket a véletlen megtévesztéseket, ami egyben azt is jelzi, hogy a machiavellisták képesek voltak rugalmasan különbséget tenni a véletlen és a szándékos megtévesztések között. 


\section{MEGBESZÉLÉS}

Eredményeink azt mutatják, hogy létezik az elmeolvasásnak egy olyan aspektusa, amelyben a machiavellisták másoknál jobbnak bizonyulnak. A manipulatív taktikus történetek mentalizációs feladataiban ugyanis jóval kevesebb hibát vétettek, mint az alacsony machiavellizmusértéket mutatók. Ez az eredmény tudomásunk szerint az első, amely kísérleti úton igazolja a machiavellizmus és az elmeolvasás pozitív irányú kapcsolatát. A machiavellisták eltérő módon értik meg a különböző történettípusokat, s míg a narratív történetekben gyengébben, addig a dialogikus történetekben másokhoz hasonló eredménnyel, a manipulatív taktikus történetekben pedig másokat felülmúlva teljesítik az elmeolvasást mérő feladatokat. Adódik a kérdés: miben rejlik a machiavellisták jobb teljesítménye a manipulatív és roszszabb teljesítménye a narratív feladatokban?

Lehetséges, hogy az alapvető cinizmusuk játszik ebben szerepet. Ha ugyanis valaki a narratív történetek szereplöihez cinikus, kétkedő hozzáállással fordul, annak a szereplők gondolatait, vágyait, szándékait leíró mentalizációs kifejezések nem feltétlenül jelentenek segítséget. Elképzelhető, hogy a machiavellisták kétkedve fogadják, és bizonyos esetekben megkérdőjelezik ezeknek a mentalizációs kifejezéseknek a valóságtartamát. Erre sarkallhatja őket az a meggyőződés, miszerint az erkölcsi normák „tévhiteit” követő emberek is készek volnának mások kihasználására, ha alkalmuk adódna, csak éppen nincsenek ennek tudatában, mert nem látják reálisan magukat (MCILWAIN, 2003). Ezek alapján pedig a machiavellisták mintegy felülírhatják a szövegben elhangzottakat: „lehet, hogy XY ezt érzi, de valójában az a szándéka...” Azt azonban, hogy egy ilyen esetleges felülírás mennyire lehet releváns, a vizsgálat keretein belül nehéz megmondani. Mindig hibás válaszként jelenik meg ugyanis, hiszen a mentalizációs kifejezésben leírtakkal ellenkező állapotot tulajdonít a szereplőnek.

A dialogikus történetek esetén nem találtunk különbséget a machiavellisták és az alacsony machiavellizmusértéket elérők elmeolvasás-teljesítménye között, ami azt jelzi, hogy a machiavellisták átlagos mértékben értették meg ezen történetek mentalizációs feladatait. Ugyanakkor, mivel a manipulatív történetek mentalizációs feladataiban másokhoz képest jóval kevesebb hibát vétettek, ez a különbség is magyarázatra szorul. A dialogikus történettípusba mentalizációs kifejezésektool megfosztott, párbeszédekre épülő történetek tartoznak, amelyek szituációk egymásba fonódó során át ábrázolják a történéseket. Mindez igaz a manipulatív történetekre is, utóbbiak azonban emellett egy-egy tipikus manipulatív taktikát is magukban foglalnak. Eredményeink alapján úgy látszik, hogy ha a valószerủ ábrázolás és a mentalizációs kifejezések hiánya mellett a történetek egy jellegzetes megtévesztő taktikát tartalmaznak, annak felismerése a machiavellisták számára kevésbé okoz problémát. Ez pedig megerősíteni látszik az elmeolvasás és a manipuláció feltételezett szoros kapcsolatát: akik könnyebben értik meg mások szándékait, hatékonyabban használhatják fel ezt saját céljaik elérésére is (SLAUGHTER és REPACHOLI, 2003; PAÁL és BERECZKEI, 2007; PAÁL, 2011). Úgy tűnik, a machiavellisták nagyon is pontosan felismerik, hogy másokat (a történet szereplőit) manipulálják. Ez magyarázható azzal, hogy a machiavellisták a manipulatív taktikus törté- 
netek mentalizációs feladatainak megoldásakor használhatták manipulációs jártasságaikat. Feltételezhető ugyanis, hogy aki maga is hajlamos különböző megtévesztő taktikák alkalmazására, az érzékenyebb ezek felismerésében. Ebben az érzékenységben, a manipulatív taktikákra való fogékonyságban szerepet játszhat az az általános cinikus hozzáállás a többi emberhez s az az általános szemlélet is, miszerint „ha én nem használok ki másokat, majd ők használnak ki engem”, amely a machiavellistákat olyannyira jellemzi (MCILwAIN, 2003). Egy további vizsgálat tárgyát képezheti annak felmérése, vajon a manipuláció felismerése mellett a taktikák alkalmazása is hasonlóan könnyen menne-e a machiavellistáknak egy olyan kísérleti játékban, amely a tipikus manipulatív taktikák alkalmazására módot ad.

Összességében azt lehet mondani, hogy a kizárólag párbeszédre épített manipulatív történetek megértésében a machiavellisták jobban teljesítenek, mint a „klasszikus”, narratívákon alapuló történetek megértésében. Ez kapcsolatba hozható azzal az elképzeléssel, miszerint a machiavellisták elmeolvasása inkább nomotetikus jellegű, szemben az alacsony machiavellizmus-pontszámot mutatók idiografikus elmeolvasásával (MCILwaIN, 2003; MEALEY, 1995; PAál, 2011). A nomotetikus elmeteória nem az egyéni különbségekre koncentrál (mint az idiografikus típusú), hanem az egyének közötti hasonlóságokból indul ki. Ahelyett, hogy az adott személyt állítaná a középpontba, akivel éppen interakció zajlik, inkább annak alapján igyekszik felmérni a másik fél mentális tartalmait, hogy hasonló emberek hasonló helyzetekben hogyan szoktak gondolkodni, cselekedni. Abból kiindulva, hogy a machiavellisták jellemzően gyors eredményre törekednek, valószínű, hogy nem próbálják meg behatóan megismerni a másik embert, sokkal inkább a gyorsan felmérhető információk és benyomások nyomán alkotnak képet, s ez alapján cselekednek (PAÁL, 2011). Az emberek közötti hasonlóságra építve jól kategorizálnak: emberismeretük miatt el tudják dönteni, hogy az ilyen és ilyen típusú emberek egy ilyen helyzetben hogyan szoktak viselkedni. Ebben ráadásul segítségükre lehet a machiavellista világnézet is, amely egyfelől cinikus, másfelől viszont reális képet tud alkotni az emberekről, azok jellemző vonásairól. Elképzelhető, hogy a mentalizációs kifejezésektől megfosztott, valószerü bemutatásra törekedő történetek jobb terepet nyújthatnak egy ilyenfajta kategorizációhoz is.

Feltűnő, hogy a párbeszédeken alapuló történeteken belül a machiavellisták másokhoz képest jobban képesek megérteni a manipulatív történeteket, mint a dialogikus történeteket. Úgy gondoljuk, ez a szituáció jellegéből fakad. A magas Mach-pontszámokkal rendelkező személyek „hazai pályán játszanak”, hiszen valószínủleg számtalan esetben vettek részt olyan interakciókban, ahol alkalom és lehetőség adódott mások megtévesztésére. A szituáció ismerős, „bennfentes” jellege és a manipuláció során elért sikerek - mint egyfajta jutalom - egyaránt indokolják, hogy a machiavellisták felülmúlják a többieket ezekben az értelmezési feladatokban.

A mentalizációs állítások egy specifikus típusában, azokban, amelyek nem az igaz-hamis dimenzió mentén különböztek, hanem cinikus vagy naiv álláspontot képviseltek, a machiavellisták az elvárásoknak megfelelően jóval többször választották a cinikus állítást, ami hűen tükrözi cinikus világnézetüket (JONES és PAULHUS, 2009; MCIlwain, 2003). Ezekből az állításokból világosan látszik, hogy amikor a 
kísérleti személyeknek lehetőségük nyílik jóhiszeműséget tulajdonítani a történetek szereplőinek, ezt a machiavellisták nem teszik meg. Ellenkezőleg: cinikus álláspontra helyezkednek, és a szereplő szándékait negatív felhanggal ítélik meg.

Vizsgálatunkban különbség mutatkozott a szándékos és véletlen megtévesztések felismerésében is. A szándékosság kérdésének megítélésekor a machiavellisták mind a narratíu, mind a manipulatív taktikus történetekben jóval határozottabban felismerték a szándékos megtévesztéseket, miközben az alacsony machiavellisták ezt többször elhibázták, véletlennek tartották. Úgy tűnik, a magas Mach-személyek a megtévesztések szándékos jellegére kifejezetten érzékenyek. Ez nem meglepő, hiszen elemi cinizmusuk, számító és gyanakvó hozzáálásuk segítségükre lehet a megtévesztés szándékosságának felismerésében is. Azok, akik elsősorban arra számítanak a másik fél részéről, hogy az megtévesztő szándékkal lép be egy társas interakcióba, feltehetően könnyebben is azonosítják be a szándékosságot.

A véletlen megtévesztések esetében viszont nem volt ilyen különbség: az alacsony és a magas Mach-személyek is hasonló módon felismerték a véletlen félrevezetéseket, félreértéseket. Bár a machiavellisták általános cinizmusa miatt nem lett volna meglepő, ha fel sem merült volna bennük, hogy a megtévesztés a véletlen műve is lehet, és ennek megfelelően szándékosnak tartották volna a véletlen megtévesztéseket is. Azonban nem ez történt, ami azt jelzi, hogy a machiavellisták alapvetően képesek a különböző helyzetek szándékos vagy véletlen jellegét helyesen megítélni. Ráadásul a szándékos megtévesztéseket másoknál jobban képesek beazonosítani. Ám hogy pontosan mit ismernek fel ilyenkor, melyek azok a jegyek, amelyek alapján a magas Mach-személyek másoknál jobban teljesítenek a szándékos megtévesztések észlelésében, annak eldöntéséhez további vizsgálatok szükségesek, amelyek részletesebben foglalkoznak a szándékosság kérdéskörével.

\section{FÜGGELÉK}

\section{Narratív történet}

Lilla és Anna jó barátnők, akik már régóta tervezik, hogy elmennek együtt egy sítúrára Szlovéniába. Mivel kettőjüknek túl drága lenne az utazás, Lilla beszervezte két ismerősét is. De mire eljött az idő, hogy lefoglalják a szállást, kiderült, hogy az ismerősök mégse tudnak velük tartani. Lilla tudta, hogy Anna mennyire vágyik erre az utazásra; nem akarta, hogy az egész az ő ismerősei miatt hulljon kútba. Ezért megkérte az unokatestvérét, Zsófit, hogy tartson velük. „Még nem tudok biztos választ adni, majd egy pár nap múlva” - mondta Zsófi. Lilla annyira örült még ennek a feltételes válasznak is, hogy azonnal beszámolt róla Annának. Másnap délelőtt Lilla azt mondta Zsófinak: „Megmondtam Annának, hogy valószínűleg te is jössz síelni, és nagyon örült neki!” Zsófi erre nem válaszolt semmit, de nagyon ideges lett. Eredetileg vissza akarta mondani az utazást, mert nem akart annyi pénzt kiadni rá. Most viszont már félt attól, hogy ha ezt teszi, Anna teljesen megbízhatatlannak fogja tartani. Úgy gondolta, ezt nem teheti meg Annával azok után, hogy az már annyiszor segített neki. Így végül úgy döntött, mégiscsak elmegy a sítúrára. 


\section{Dialogikus történet}

Melinda irodája. András, Melinda párja benyit az ajtón.

András: Szia Melcsi, milyen napod volt?

Melinda: Szia, drágám! De jó, hogy bejöttél. Mindjárt végzek. Mit szólnál, ha elmennénk vacsorázni?

András: Hát az nagyon jó lenne, de az előbb összefutottam a folyosón Simonnal, és megbeszéltük, hogy elmegyünk fallabdázni. De majd utána felugrok hozzád. Főzhetnél valami finomat. Úgyis olyan ritkán ehetem a főztödet.

Melinda: Ritkán. Ühüm. Hát ez meg mit akar jelenteni?

András: Ó, semmit, semmit. Csak olyan finomakat fózöl, hogy többször is ehetnénk... Meg beszélgettem Simonnal, és tudod, rá minden nap föznek... olyan jó érzés lehet.

Melinda: Szóval Simon? Értem. Biztos vagyok benne, hogy Simon anyukája minden nap finom ételekkel várja otthon egyetlen fiacskáját, de Simon anyukája tudtommal nyugdíjas! És nem ül bent egy irodában napi tíz órát.

András: Jó, jó, értem. Semmi gond, csak egy felvetés volt. Akkor este! Puszi.

Melinda irodája. Néhány nappal később. Simon egy halom CD-vel a kezében áll az ajtóban.

Simon: Szevasz, Melcsike!

Melinda: Melinda, ha kérhetem. Szia, Simon!

Simon: Elvinnéd ezeket Andrásnak? Ma kivételesen nem találkozunk. Randim lesz, bár amennyire ma meg lehet bízni a nőkben... De muszáj Andrásnak még ma megkapnia, szóval?

Melinda: Simon, azt se tudom, hol áll a fejem! Rengeteg munkám van még. Nem biztos, hogy ma oda tudom adni neki. Különben sem fér el a táskámban ennyi CD.

Aznap este András és Melinda a lány lakásában beszélgetnek.

András: Nem küldött nekem CD-ket Simon?

Melinda: Hú, nem... de volt bent nálam, és kérdezte, benézel-e ma hozzám, mert oda kellene adnia neked valami CD-ket.

András: A francba, ez nagyon fontos lett volna!

Melinda: Én mondtam neki, hogy elhozom őket, de valami olyasmit válaszolt, hogy a nőkben nem lehet megbízni.

András: Áá, Simonra soha nem lehet igazán számítani. Pedig a barátom... és még téged tart megbízhatatlannak? Talán itt az ideje, hogy kissé elgondolkozzunk ezen a barátságon.

Melinda: (lesüti a szemét) Ahogy gondolod, András.

\section{Manipulatív taktikus történet}

A ruhaüzletben az eladó és az üzletvezető háttal a bejáratnak halkan beszélgetnek. Az üzlet ajtaja kinyílik, és finom, dallamosan csengő hang jelzi, hogy vendég érkezett. Egyszerre fordulnak hátra, majd az eladó a vevő köszöntésére siet, az üzletvezetö pedig hátul eltünik a raktárban.

Eladó: Jó napot kívánok! Miben segíthetek?

Vásárló: Jó napot kívánok! Olyan szép kabátok vannak a kirakatban. Megnézném. Egy elegáns, de hétköznap is hordható szövetkabátot keresek. 
Eladó: Kabátot? Bocsásson meg, de kissé... rossz a hallásom.

Vásárló: Igen, kabátot. Sz-ö-v-e-t-k-a-b-á-t-o-t!

Eladó: $\quad$ Akkor erre tessék. Itt vannak a szövetkabátjaink.

A vásárló nézegeti és próbálgatja a kabátokat, miközben az eladó készségesen dicséri. A vásárló sokat forgolódik, végül az utolsóként felvett modellen elkezdi keresni az árcédulát. A cédulát megtalálja, de csak az általános információkat tartalmazza, ár nincs rajta. Az eladóhoz fordul.

Vásárló: Nem találom az árát. Mennyibe kerül ez a kabát?

Eladó: Ho... hogy mondja? Kicsit hangosabban, ha kérhetem.

Vásárló: Nincs rajta ár. M-i-b-e k-e-r-ü-l?

Az Eladó a raktár felé fordul: Erzsike! Mennyibe kerül ez a kabát?

Az Üzletvezető kidugja a fejét a raktárból: Az a gyönyörű kasmír szövetkabát? Hatvankétezer.

Az Eladó a kezét a füléhez emelve: Mennyi?

Üzletvezetö: H-a-t-v-a-n-k-é-t-e-z-e-r!

Az Eladó a vevőhöz fordul: Azt mondja, harminckétezer forint.

Vásárló: Rendben, akkor megveszem.

Mindketten a pulthoz sietnek, a vásárló kifizeti a harminckétezer forintot, és távozik a kabáttal. Amint becsukódik az üzlet ajtaja, az üzletvezetö kijön a raktárból, és mosolyogva vállon veregeti az eladót.

Üzletvezetö: Ma is jó üzletet csináltunk.

\section{IRODALOM}

Ali, F., \& Chamorro-Premuzic, T. (2010). Investigating theory of mind deficits in nonclinical psychopathy. Personality and Individual Differences, 49, 169-174.

Austin, J. E., Farrelly, D., Black, C., \& Moore, H. (2007). Emotional Intelligence, Machiavellianism and emotional manipulation: Does EI have a dark side? Personality and Individual Differences, 43, 179-189.

BereczKei T. (2009). Az erény természete. Önzetlenség, együttmüködés, nagylelküség. Budapest: Typotex.

Bereczkei, T., BirkÁs, B., \& Kerekes, Zs. (2010). The presence of others, prosocial traits, Machiavellianism: A Personality X Situation approach. European Journal of Social Psychology, 41, 238-245.

Bereczkei, T., Deák, A., PApp, P., Perlaki, G., \& Orsi, G. (2013) Neural correlates of Machiavellian strategies in a social dilemma task. Brain and Cognition, 82, 108-116.

Buss, D. M., Gomes, M., Higgins, D. S., \& LauerbaCH, K. (1987). Tactics of manipulation. Journal of Personality and Social Psychology, 52(6), 1219-1229.

Christie, R., \& Geis, F. (Eds.) (1970). Studies in Machiavellianism. New York: Academic Press.

Czibor, A., \& BERECZKEI, T. (2012). Machiavellian people's success results from monitoring their partners. Personality and Individual Differences, 53, 202-206.

Gunnthorsdottir, A., MCCabe, K., \& SMith, V. (2002). Using the Machiavellianism instrument to predict trustworthiness in a bargaining game. Journal of Economic Psychology, 23, 49-66. 
Harrell, W. A. (1980). Retaliatory aggression by high and low Machiavellians against remorseful and nonremorseful wrongdoers. Social Behavior and Personality, 8, 217-220.

Harrell, W. A., \& Hartnagel, T. (1976). The impact of Machiavellianism and the trustfulness of the victim on laboratory theft. Sociometry, 39, 157-165.

Jones, D. N., \& Paulhus D. L. (2009). Machiavellianism. In M. R. Leary, \& R. H. Hoyle (Eds.), Individual Differences in Social Behaviour (93-108). New York: Guilford.

Kinderman, P., Dunbar, R. I. M., \& Bentall, R., P. (1998). Theory-of-mind deficits and causal attributions. British Journal of Psychology, 89, 191-204.

Lyons, M., Caldwell, T., \& SChultz, S. (2010). Mind-reading and manipulation - Is Machiavellianism related to theory of mind? Journal of Evolutionary Psychology, 8(3), 261-274.

MCIlwaIn, D. (2003). Bypassing empathy: A Machiavellian theory of mind and sneaky power. In B. Repacholi, \& V. Slaughter (Eds.), Individual Differences in Theory of Mind (39-66). Hove, E. Sussex: Psychology Press.

MEALEY, L. (1995). The sociobiology of sociopathy: An integrated evolutionary model. Behavioral and Brain Sciences, 18(3), 523-599.

PAÁL, T., \& BereczKeI, T. (2007). Adult theory of mind, cooperation, Machiavellianism: The effect of mindreading on social relations. Personality and Individual Differences, 43, $541-551$.

PAÁL T. (2011). Machiavelliánus döntéshozó stratégiák a szociális kapcsolatokban. A manipulatív viselkedés evolúciós perspektívája. Doktori (PhD) értekezés.

SíkLAKi I. (2009). A manipuláció arcai. Szociálpszichológiai kitekintés. In SimON G. (szerk.), Báránybörben. A nyílt agressziótól a manipulációig (269-341). Budapest: Háttér.

SimON G. (szerk.) (2009). Báránybörben. A nyílt agressziótól a manipulációig. Budapest: Háttér.

Slaughter, V., \& Repacholi, B. (2003). Introduction: Individual differences in theory of mind: What are we investigating? In B. Repacholi, \& V. Slaughter (Eds.), Individual Differences in Theory of Mind (1-12). Hove, E. Sussex: Psychology Press.

Whiten, A., \& Byrne, R. (1997). Machiavellian Intelligence II. Cambridge: Cambridge University Press.

Wilson, D. S., NeAR, D., \& Miller, R. R. (1996). Machiavellianism: A Synthesis of the evolutionary and psychological literatures. Psychological Bulletin, 119(2), 285-299.

Wilson, D. S., NEAR, D., \& Miller, R. R. (1998). Individual differences in Machiavellianism as a mix of cooperative and exploitative strategies. Evolution and Human Behavior, 19, 203-212.

\title{
MINDREADING AND MACHIAVELLIANISM: THE SITUATED MAPPING OF MANIPULATION
}

\author{
SZABÓ, EDIT - BERECZKEI, TAMÁS
}

Theoretically, successful manipulation predicts high levels of mindreading capacity, though the former researches on Machiavellianism could not prove this issue. Therefore, the possibility arises that Machiavellians actually achieve lower levels of cognitive performance than previously thought. How- 
ever, there are other research findings that seem to contradict this, stating that Machiavellian individuals successfully manipulate others and to this end, they also use their impressions formed of the other participants in the given social interaction. We assumed that this contradiction can be solved, if we create a new approach to the mindreading of the Machiavellians. In this study we used a new method which - based on dialogues - presents a kind of stimulus similar to real-life social contexts, and also brings the use of manipulative tactics into focus. We found that high Machs solve the mentalization tasks of dialogue-based stories better than those of narrative-based stories. Machiavellians proved to be better than others in the mindreading tasks of manipulative-style stories and showed a specific sensibility on recognizing the intentionality of the deception. Accordingly, these findings can throw new light upon Machiavellians theory of mind.

Key words: mindreading, theory of mind, Machiavellianism, manipulation 